\title{
Species diversity and distribution of mud crab in Marudu Bay mangrove forest reserve, Sabah, Malaysia
}

\author{
Nurul Ain Mohd Sharif, Noor Amalia Shaiful Kahar, Muhammad Ali Syed Hussein, Julian Ransangan and \\ Annita Seok-Kian Yong *
}

Borneo Marine Research Institute, Universiti Malaysia Sabah, Jalan UMS, 88400 Kota Kinabalu, Sabah, Malaysia

*Corresponding author: annitay@ums.edu.my

\begin{abstract}
Sabah has extensive mangrove forests surrounded by oceanic waters which provide suitable habitat for many species of animals including mud crabs (Scylla spp.). This study was conducted to obtain information on the species composition, distribution and catch per unit effort in Marudu Bay, Sabah. Samplings were done monthly in five mangrove areas along the river channels in Marudu Bay $\left(06^{\circ} 33^{\prime} \mathrm{N}\right.$; 114 ${ }^{\circ} 44^{\prime} \mathrm{E}$ ) from October 2012 to September 2013 using collapsible baited crab traps. From a total of 1859 mud crab specimens caught in Marudu Bay, three species were identified. Scylla tranquebarica was the dominant species forming $78 \%$ of the total followed by S. paramamosain $13 \%$ and S. olivacea $8 \%$. The number of males $(n=1224)$ was higher compared to females $(n=635)$ with an average sex ratio male : female of 1.0:0.5. The catch per unit effort (CPUE) showed an average value of 0.55 trap $^{-1}$ day $^{-1}$ and revealed a declining trend throughout the sampling. $S$. tranquebarica was widely distributed in all the rivers surveyed, however, it mostly occurred in near the lower reaches of the river near the areas open to the sea where average water salinity ranged from 12.98 to $14.28 \mathrm{ppt}$ and the environment favoured the growth of Rhizophora sp. Other species, S. paramamosain and S. olivacea, were mostly found in upstream areas covered generally by Nypa sp. and where average water salinity varied from 6.93 to $7.50 \mathrm{ppt}$. The information on the species composition, distribution and CPUE of the mud crabs in Marudu Bay can be useful for mud crab fisheries resources management in Sabah.
\end{abstract}

Keywords: Mud crab, Species composition, Species distribution, Scylla spp., Sabah

\section{Introduction}

Mud crabs of the genus Scylla, also known as mangrove crabs, inhabit coastal waters associated with mangrove swamps and nearby intertidal and sub-tidal muddy habitats throughout the Indo-West Pacific region (Keenan et al., 1998). Mud crabs have high commercial value due to increasing demand locally and internationally. However, the supplies depend on the wild caught mud crab. Farmers capture juveniles from the natural populations for growout and softshell crab production. For meeting the demand of bigger size crabs the grow-out is done through the methods of fattening. This has resulted in high exploitative and decline the the numbers of large-sized of mud crab in the catch and amount of landings worldwide (Angell, 1992; Keenan, 1999; Dumas et al., 2012). Although seed production of mud crab has been established, however, the production is limited. For this reason the pressure on the wild populations of crabs still remains high.

There are four species of mud crabs, namely Scylla serrata (Forskål, 1775), S. tranquebarica (Fabricius, 1798), $S$. olivacea (Herbst, 1796) and $S$. paramamosain (Estampador, 1949). Scylla serrata is the most common of these species, and has a wide distribution throughout the western Indian Ocean, Japan and South Pacific Islands. Scylla tranquebarica and S. olivacea are more commonly found in the South China Sea, extending into the Indian Ocean and western Pacific (Keenan et al., 1998). Scylla paramamosain has a limited distribution, being restricted to regions of south China and the Java Seas (Keenan et al., 1998; Le Vay et al., 2001).

In Malaysia, three species of mud crab: $S$. tranquebarica, $S$. paramamosain and $S$. olivacea were reported in Terengganu (Ikhwanuddin et al., 2010), Kelantan (Ihwan et al., 2011), Johor (Azmie et al., 2012) and Sarawak (Ikhwanuddin et al., 2011). Sabah is one of the main seafood exporters in Malaysia. The export includes the mud crabs. It also has the most extensive mangrove forest cover (341,000 ha) which contributes to a significant amount of seafood resources, including mud crabs (Faridah-Hanum et al., 2012). However, there is a paucity of investigations on the mud crab resources. For sustainable fisheries resources management, information on their population and other aspects is needed for framing the guidelines. Therefore, this study was conducted on the mangrove crabs to gain information on species composition, distribution and catch per unit effort in Marudu Bay mangrove forest reserve, Sabah. Marudu Bay is one of the pristine mangrove areas in Sabah covering an area of 9550 ha of (Ransangan and Tan, 2018).

\section{Materials and Methods}

\section{Sampling area and procedure}

Mangrove area of Marudu Bay (06³3'N; 114²4'E) in Sabah coastal waters was chosen as the study site (Figure 1). 
Monthly samplings were carried out for 12 months from October 2012 until September 2013, and each sampling was conducted for two to three days.

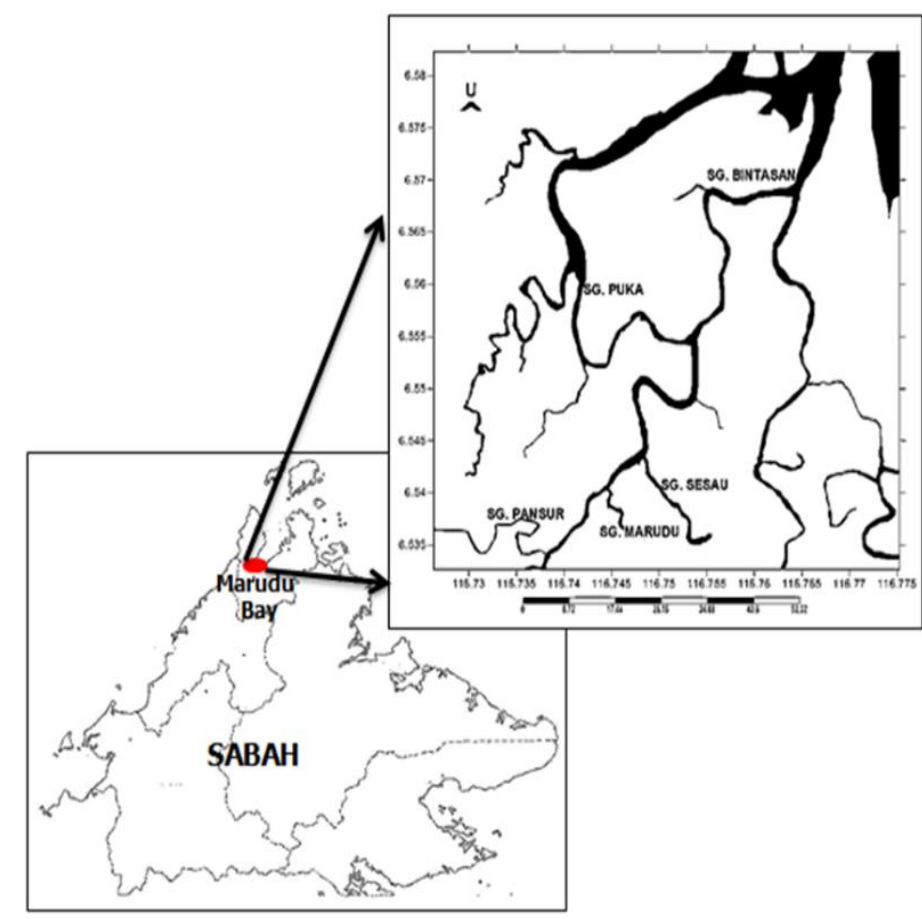

Figure 1. Map of study areas in Marudu Bay, Sabah, Malaysia.

During the sampling, 50 collapsible baited crab traps $(50 \mathrm{~cm} \times 25 \mathrm{~cm})$ with entrance on two sides were used. In each sampling effort, the traps were deployed for about one to two hours in the water along the river twice daily. The traps were deployed during low tide and collected during high tide. The number and sex of the crab specimens caught in each trap were recorded. Thereafter, the crabs were tied and marked with paint marker. The location where the crabs were caught was recorded using global positioning system (GPS). In-situ water quality parameters including salinity, $\mathrm{pH}$, dissolved oxygen and temperature were measured using portable multiparameter water quality meter (Hanna Instruments, HI 9828, Washington, USA). The species of mangrove trees in each sampling site was identified and recorded. In order to study the spatial distribution of the mud crabs in Marudu Bay, five rivers in the Marudu Bay were chosen as the study areas which included Puka River, Marudu River, Sesau River, Pansur River and Bintasan River. The samplings were assisted by local fishermen who have local knowledge and experience on baited crab fishing in the study areas. The crabs were then brought to Borneo Marine Research Institute, Universiti Malaysia Sabah, for species identification and measurements. The species were identified based on the morphological characteristics following Keenan et al. (1998).

\section{Data analysis}

The data on species identification and sex were used to determine sex ratio of the different the crabs in Marudu Bay. Information on species composition was presented as the cumulative number of the respective species caught during the study period. Average value of catch per unit effort (CPUE) was determined based on the total number and weight of mud crabs caught as suggested by Stamatopoulos (2002). The data obtained were computed using Microsoft Office Excel 2011. For species distribution, the marked coordinates read from the GPS during the samplings were transferred to Garmin Map source software to visualise the plotted coordinates. The map from Google Earth aerial photo was used as a base map. The coordinates of the distribution were then plotted using Surfer software version 8.0 to summarise the distribution pattern of each mud crab species.

\section{Results}

Three species of mud crabs were identified in Marudu Bay; the purple mud crab $S$. tranquebarica, green mud crab $S$. paramamosain and orange mud crab $S$. olivacea. From the total of 1859 mud crab specimens caught in Marudu Bay, $S$. tranquebarica appeared to be the dominant species, forming $78.43 \%(\mathrm{n}=1458)$ of the total number, followed by $S$. paramamosain with $13.23 \%(\mathrm{n}=246)$ and S. olivacea with $8.34 \%(n=155)$ (Table 1). Overall, the total number of male crabs $(n=1224)$ was nearly two times higher than that of the female $(n=635)$ with an overall sex ratio male : female of 1.0:0.5. The sex ratio male: female of $S$. tranquebarica, $S$. paramamosain and $S$. olivacea was 1.0:0.5, 1.0:0.9 and 1.0:0.4, respectively. The body weight of male crabs was higher than the females. $S$. tranquebarica males were significantly heavier compared to the females $(\mathrm{p}<0.05)$. Males S. paramamosain and S. olivacea were also heavier compared to females. The male and female of $S$. tranquebarica recorded the biggest body weight of $730 \mathrm{~g}$ and $370 \mathrm{~g}$, respectively among the three species. During the sampling, no berried female was caught in the study areas.

Table 1. Species composition, sex ratio and body weight of mud crabs caught in the mangrove area of Marudu Bay

\begin{tabular}{|c|c|c|c|c|c|c|}
\hline \multirow[b]{2}{*}{ Species } & \multirow[b]{2}{*}{ Sex } & \multirow[b]{2}{*}{$\mathbf{N}$} & \multirow{2}{*}{$\begin{array}{l}\text { Sex } \\
\text { ratio } \\
\text { M:F }\end{array}$} & \multicolumn{3}{|c|}{ Body weight (g) } \\
\hline & & & & $\begin{array}{l}\text { Mean } \\
\pm \text { SD }\end{array}$ & Min & $\operatorname{Max}$ \\
\hline$S$. & M & 980 & $\begin{array}{l}1.0: \\
0.5\end{array}$ & $\begin{array}{l}191.08 \\
\pm 118.65\end{array}$ & 30 & 730 \\
\hline tranquebarica & $\mathrm{F}$ & 478 & & $\begin{array}{l}132.36 \\
\pm 61.64\end{array}$ & 30 & 370 \\
\hline \multirow[t]{2}{*}{$\begin{array}{l}\text { S. } \\
\text { paramamosain }\end{array}$} & M & 131 & $\begin{array}{l}1.0: 0 . \\
9\end{array}$ & $\begin{array}{l}157.02 \\
\pm 86.84\end{array}$ & 50 & 550 \\
\hline & $\mathrm{F}$ & 115 & & $\begin{array}{l}135.91 \\
\pm 49.45\end{array}$ & 50 & 270 \\
\hline \multirow[t]{2}{*}{ S. olivacea } & M & 113 & $\begin{array}{l}1.0: 0 . \\
4\end{array}$ & $\begin{array}{l}207.79 \\
\pm 105.89\end{array}$ & 70 & 540 \\
\hline & $\mathrm{F}$ & 42 & & $\begin{array}{l}184.76 \\
\pm 65.34\end{array}$ & 80 & 300 \\
\hline
\end{tabular}


The monthly species composition also showed that the number of $S$. tranquebarica caught was consistently higher than the other two species throughout the 12 months sampling from October 2012 to September 2013 (Figure 2). While $S$. tranquebarica can be found abundantly throughout the year, S. paramamosain was mostly found in June until November while only small numbers of $S$. olivacea was found in every sampling effort in Marudu Bay.

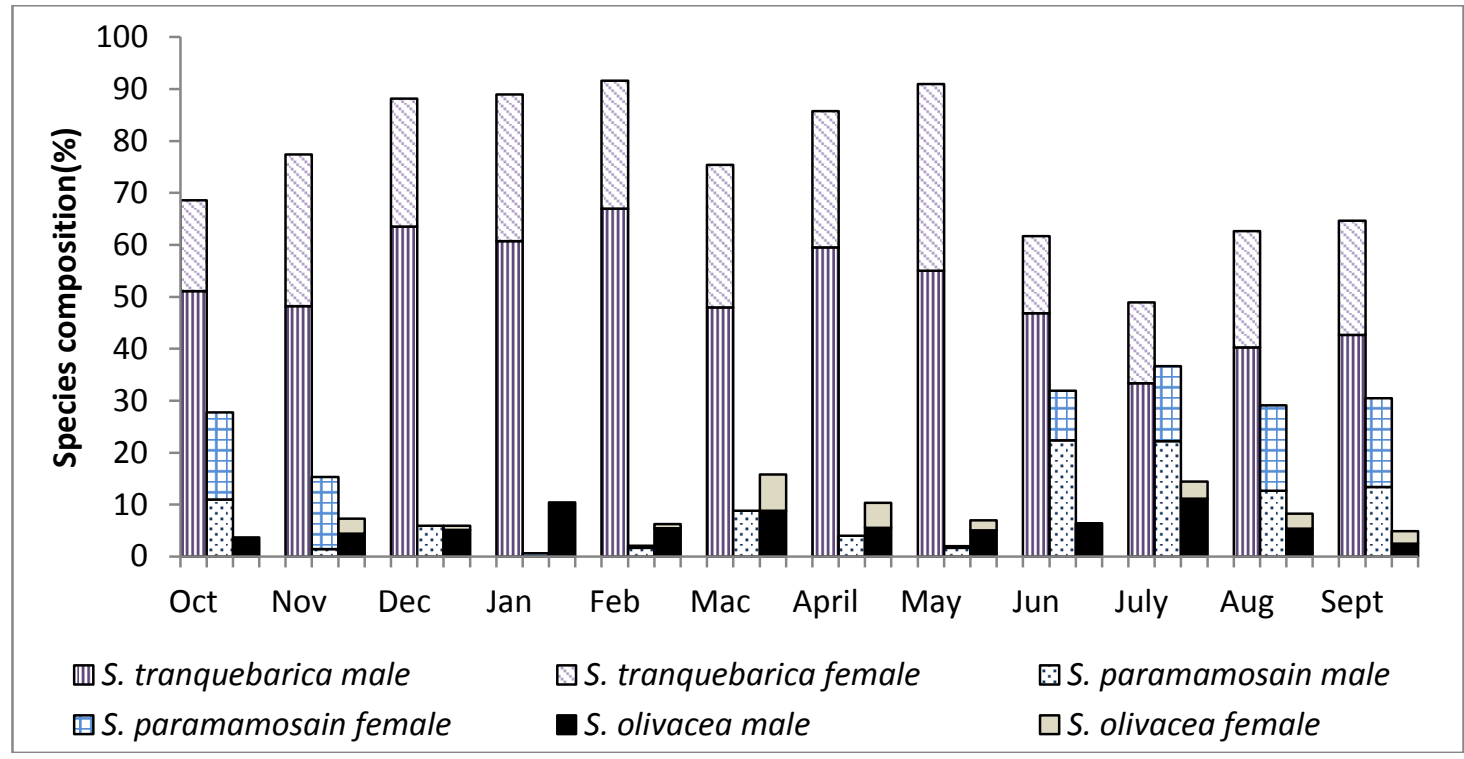

Figure 2. Monthly species composition of mud crabs in Marudu Bay.

The mean value of the CPUE of the crabs caught in Marudu Bay mangrove area was estimated at $0.55 \mathrm{crabs} \mathrm{trap}^{-1} \mathrm{day}^{-1}$ or 91.47 gram trap $^{-1}$ day $^{-1}$ (Figure 3). The value of CPUE ranged from highest at $0.67 \mathrm{crab} \mathrm{trap}^{-1} \mathrm{day}^{-1}$ in 0 ctober 2012 , and it gradually declined to $0.41 \mathrm{crabs}^{\mathrm{trap}}{ }^{-1} \mathrm{day}^{-1}$ in Sept 2013. In the present study, the highest catch was 67 crabs per day while only 41 crabs per day when the yield was poor.



Figure 3. Catch per unit effort of mud crabs caught in Marudu Bay from October 2012 to September 2013.

The species distribution in the five rivers in Marudu Bay mangrove areas is presented in Figures 4 and 5. The data showed that all the three species of mud crabs; S. tranquebarica, S. paramamosain and S. olivacea occurred in these five riverine habitats of Marudu. Scylla tranquebarica was found in all the study areas but most abundant in Bintasan River and Puka River where the mean water salinity was 14.98 ppt and 12.98 ppt, respectively. These two rivers were nearer to the open sea and the mangrove was dominated by Rhizophora sp. While S. paramamosain and S. olivacea were mostly distributed in Sesau River, Pansur River and Marudu River where lower mean water salinity ranging from 6.93 to 7.50 ppt. prevailed. The mangrove cover in these rivers mostly comprised Nypa sp.. 


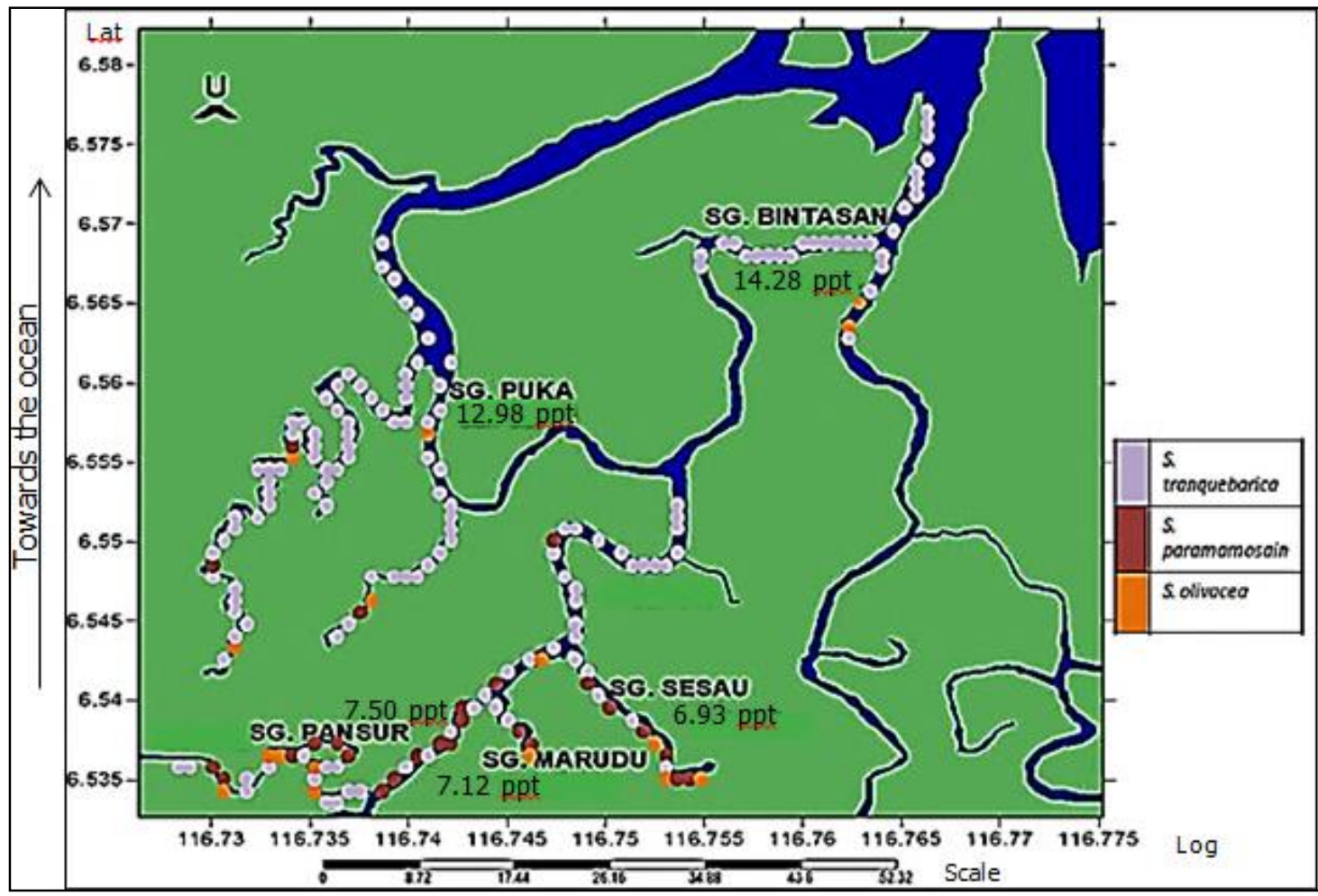

Figure 4. Species distribution of mud crabs in rivers of Marudu Bay mangrove area with mean water salinity.

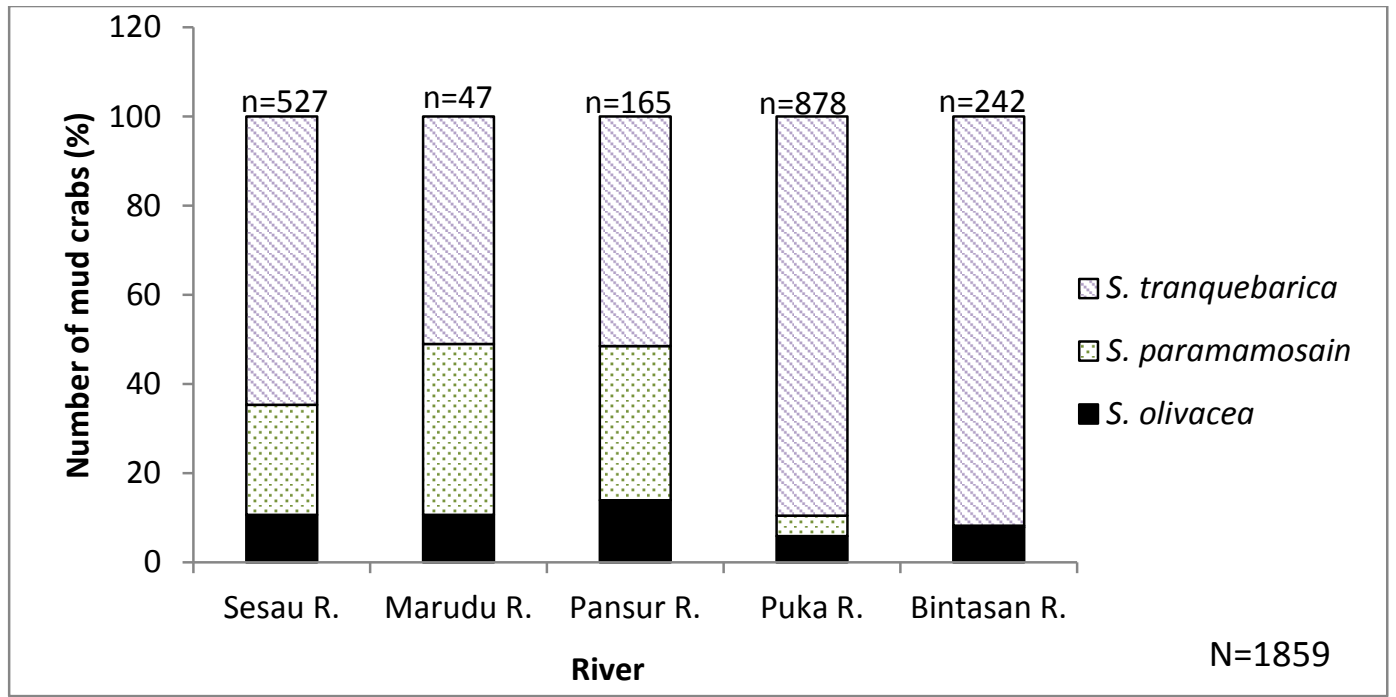

Figure 5. Species distribution of mud crabs in Marudu Bay. (*R- River)

The distribution of $S$. tranquebarica was positively $\left(\mathrm{R}^{2}=0.67\right)$ related to water salinity, while the reverse trend was observed in the distribution of $S$. paramamosain $\left(\mathrm{R}^{2}=0.9\right)$ and $S$. olivacea $\left(\mathrm{R}^{2}=0.90\right)$ (Figure 6$)$. The other in-situ water parameter such as $\mathrm{pH}$, water temperature and dissolved oxygen did not appear to significantly affect the distribution of the mud crabs in the study areas (Table 2). 


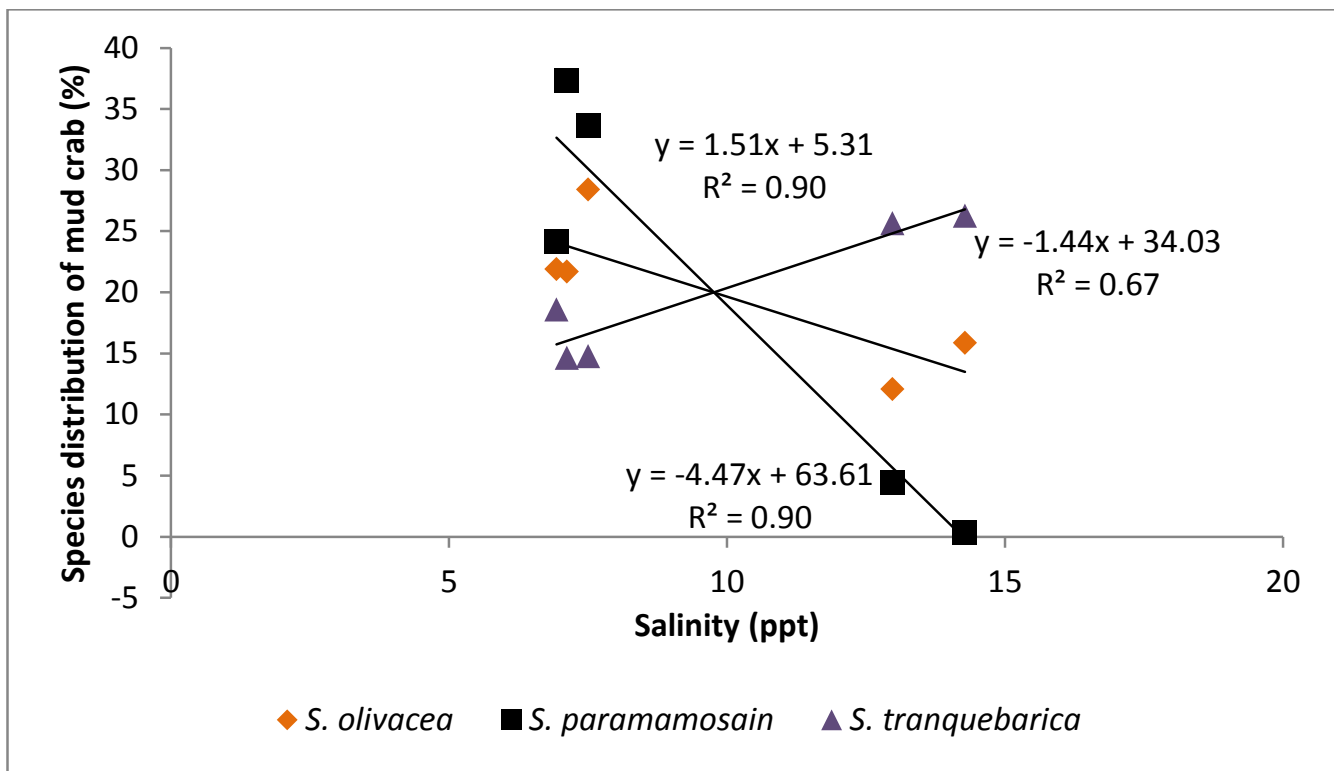

Figure 6. Species distribution of mud crabs in areas with different water salinity in five rivers of Marudu Bay.

Table 2. Water quality parameters in the mangrove area of Marudu Bay

\begin{tabular}{|c|c|c|c|c|}
\hline $\begin{array}{c}\text { River/ } \\
\text { Variable }\end{array}$ & $\begin{array}{c}\text { Water } \\
\text { salinit } \\
y \\
\text { (ppt)* }\end{array}$ & $\begin{array}{l}\text { Dissolved } \\
\text { oxygen } \\
(\%)\end{array}$ & $\mathrm{pH}$ & $\begin{array}{c}\text { Water } \\
\text { Temperature } \\
\left({ }^{\circ} \mathrm{C}\right)\end{array}$ \\
\hline Bintasan & 14.28 & 57.25 & 7.13 & 28.94 \\
\hline River & \pm 3.44 & \pm 8.84 & \pm 0.13 & \pm 0.76 \\
\hline Puka & 12.98 & 49.26 & 7.33 & 28.00 \\
\hline River & \pm 7.88 & \pm 15.11 & \pm 0.63 & \pm 3.70 \\
\hline Marudu & 7.12 & 48.80 & 7.47 & 28.26 \\
\hline River & \pm 6.00 & \pm 13.15 & \pm 0.32 & \pm 0.28 \\
\hline Sesau & 6.93 & 51.21 & 7.46 & 27.54 \\
\hline River & \pm 4.79 & \pm 15.94 & \pm 0.34 & \pm 1.81 \\
\hline Pansur & 7.50 & 39.63 & 7.56 & 27.19 \\
\hline River & \pm 5.40 & \pm 7.25 & \pm 0.36 & \pm 0.74 \\
\hline
\end{tabular}

\section{Discussion}

In the present study, three out of the four species of Scylla spp. mud crabs that have been reported were found in Marudu Bay. They are $S$. tranquebarica, $S$. paramamosain and $S$. olivacea. $S$. serrata is a species common elsewhere but it was not seen in the Marudu Bay mangrove areas. Among the three species, the biggest size of male and female specimens caught was from $S$. tranquebarica. The males were bigger than the females in all of the species. These three closely related species were also reported in Terengganu (Ikhwanuddin et al., 2010), Kelantan (Ihwan et al., 2011), Johor (Azmie et al., 2012) and Sarawak (Ikhwanuddin et al., 2011). For the mud crab, it is common for several species to occur in one location but only only one species making up the higher percentage of overall crab population (Shelly and Lovatelli, 2011). In Marudu Bay, $S$. tranquebarica was found to be the dominant species, followed by $S$. paramamosain whereas the abundance of $S$. olivacea was lowest. This pattern of occurrence and abundance was consistently observed throughout the year in Marudu Bay. In comparison with other mud crab studies in Malaysia, S. paramamosain and S. olivacea were reported as the major species in Kelantan and Terengganu, respectively while the population strength of $S$. tranquebarica was lowest (Ikhwanuddin et al., 2010; Ihwan et al., 2011). Meanwhile, S. olivacea was the major species in Sarawak (Ikhwanuddin et al., 2011). In other Southeast Asian countries, Thailand, Philippines and Indonesia, $S$. olivacea was reported as the dominant species. In Ranong, Thailand, $S$. olivacea was found together with $S$. paramamosain was the dominant species (Tongdee, 2001). Meanwhile, in Panay Island, Philippines, the catch composition was documented: Scylla olivacea (99.34\%), Scylla tranquebarica $(0.58 \%)$ and Scylla serrata $(0.08 \%)$ (Walton et al., 2006). In Southeast Sulawesi, Indonesia $S$. serrata was the dominant species (Sara, 2010). The present study supported the suggestion that species composition of mud crabs varies in different locations even in the same country (Ikhwanuddin et al., 2011).

The present study further showed that the number of male crabs caught was almost two times higher compared to the females in Marudu Bay. Similar observations were reported earlier (Jirapunpipat, 2008; Ikhwanuddin et al., 2011). Lower number of females may be due to the possibility of females occupying specific ecological niches and were not attracted to the baited trap (Ward et al., 2007). The other reason could be the migration of berried females from the mangrove area to the ocean for spawning (Ward et al., 2007) where they stop feeding and are thus less susceptible to baited traps (Heasman et al., 1985). In present study, no single berried female was caught in the rivers, although matured females (gonado-somatic index 
10.7) can be obtained throughout the sampling period (Noor Amalia, 2016). This may indicate that the female undergoes gonad maturation in the mangrove area and then moves out to the ocean for spawning. The lower percentage of $S$. tranquebarica female caught in Jun and July was coincided with the spawning season in Marudu Bay (Noor Amalia, 2016). This might be one of the reasons contributing to lower number of females caught in the mangrove areas.

A decline in CPUE was evident throughout the sampling period from October 2012 (0.67 crabs trap $^{-1}$ day $^{-1}$; 116.6 gram trap $^{-1}$ day $^{-1}$ ) to September 2013 (0.41 crabs trap${ }^{1}$ day $^{-1} ; 60.4$ gram trap $^{-1}$ day $^{-1}$ ). A separate sampling back to the study areas in April 2014 showed that CPUE was 0.54 crab specimens trap ${ }^{-1}$ day $^{-1}$. These CPUE values were comparable to a study on $S$. serrata in a non-reserve fishing ground in Australia (Pillans et al., 2005). However, the CPUE values were lower compared to $S$. serrata caught in marine reserves that were closed for fishing for five years (Pillans et al., 2005). The CPUE was 2.5 times higher in the marine reserves than the non-reserves sites (Pillans et al., 2005). In Marudu Bay, the northeast and southwest monsoon could have influenced the catch. The northeast monsoon season (October to March) usually brings heavy rainfall and the catch of mud crab in Marudu Bay was higher during these month. It may due to food availability like detritus and prey in muddy waters (Nirmala et al., 2012). Besides that, estimated data using FiSAT software (FAO-ICLARM Fish Stock Assessment Tools) showed that recruitment of younger crabs occurred around June to September (Nurul Ain, 2016). These small sized crabs may easily get in and out of the traps without being caught, thus contributing to lower CPUE value in this study. Other factors such as overfishing, environment, or physical changes in the habitat and pollution are also known to affect the mud crab abundance (Hutchinson et al., 2014). Decline of crab landings and smaller average size in the catch have been reported over the last two decades (Angell, 1992; Le Vay, 2001; Lebata et al., 2007). More data and longer study period are needed to understand if overfishing or other factors is reducing the CPUE in Marudu Bay.

Keenan et al. (1998) have suggested that the four Scylla species may have diverged distribution based on their tolerance to salinity. In the present study, $S$. tranquebarica were found as the dominant species in five rivers of Marudu Bay forest reserve where the water salinity ranged from 6.93 to 14.28 ppt. However, S. tranquebarica was mostly distributed in Puka River and Bintasan River that are located near the open sea. This was supported by previous study reporting that $S$. tranquebarica was relatively more common in the sub-tidal areas and moves towards mangroves during flood tides for feeding (Walton et al., 2006). S. paramamosain and S. olivacea were mostly caught in areas with lower water salinity (Sesau, Marudu and Pansur River). Earlier studies also reported that these two species prefer moving to low salinity areas near the river mouths and ascend farther upstream areas that are not easily accessed by boat (Keenan et al., 1998; Walton et al.,
2006; Ewel et al., 2009). Keenan et al. (1998) further stated that $S$. olivacea is limited to mangroves and coastline with reduced water salinity especially during the rainy season. For other variable water parameters, temperature, $\mathrm{pH}$ and dissolved oxygen were not shown to have any effect on the distribution of these three mud crab species in Marudu Bay. Types of vegetation might also be a factor in the distribution. In this study, rivers that are closer to the open sea (Bintasan and Puka River) were dominated with Rhizophora sp.. The areas further upstream and close to the land (Pansur, Marudu and Sesau River) were dominated by Nypa sp. The local fishermen also expressed the view that $S$. tranquebarica was known as the 'mangrove crab' which they mostly noticed in the mangrove vegetation, while $S$. olivacea was known as the 'nypa crab' due to its abundance in in nypa forest.

In the present study, no $S$. serrata was found. However, the local fishermen reported to have caught occasionally caught this mud crab species with individual body weight exceeding $1 \mathrm{~kg}$ as the by-catch when fishing in the open sea. There is a possibility that $S$. serrata is present in Sabah coastal waters as reported by Ikhwanuddin et al. (2014). However, due to the sampling sites in the present study were in the mangrove areas S.serrata could not be seen in the samples but may be present in its favourite habitat of high salinity oceanic waters (Keenan et al., 1998). The specific reasons for species distribution over a large area with different habitats could be linked to multiple factors that need further investigations (Walton et al., 2006).

\section{Conclusion}

Present study showed that three different species of mud crabs with wide range of sizes can be caught with the baited traps in the mangrove area of Marudu Bay. Mangrove area in Marudu Bay provides an important habitat that can shelter for different species and support the requirements of different stages of mud crabs. Although the three species of mud crabs were found associated with each other within the same mangrove area, the distribution their distribution is strongly influenced by the water salinity. A more comprehensive study over a longer period is needed to clarify the possible reasons for the decreasing trend of CPUE of the crabs in Marudu Bay.

\section{Acknowledgement}

This study was financially supported by Ministry of Science, Technology and Innovation Malaysia under the eScience Fund research grant 04-01-10-SF0167 (SCF0077-SEA2012). 


\section{References}

Angell, C.A. (1992). Summary of the proceedings of the seminar on the mud crab. In The mud crab: report of the seminar on mud crab culture and trade. Bay of Bengal Programme. (C.A Angell ed.) pp1-4. Madras, India.

Azmie, G.A.B., Abol-Munafi, W.W.Y., Faizal, M. \& Ikhwanuddin, M. (2012). Ovarian maturation stages of orange mud crab, Scylla olivacea. In $1^{\text {th }}$ International Annual Symposium on Sustainability Science and Management, pp. 58-64. Universiti Malaysia Terengganu, Terengganu, Malaysia.

Dumas, P., Léopold, M., Frotté, L. \& Peignon, C. (2012). Mud crab ecology encourages site specific approaches to fishery management. Journal of Sea Research 67, 1-9.

Ewel, K. C., Rowe, S., McNaughton, B. \& Bonine, K.M. (2009). Characteristics of Scylla spp. (Decapoda: Portunidae) and their mangrove forest habitat in Ngaremeduu Bay of Palau. Pacific Science 63, 15-26.

Faridah-Hanum, I., Kudus, K.A. \& Saari, N.S. (2012). Plant diversity and biomass of Marudu Bay Mangroves in Malaysia. Pakistan Journal of Botany 44, 151-156.

Heasman, M.P., Fielder, D.R. \& Shepherd, R.K. (1985). Mating and spawning in the mud crab Scylla serrata (Decapoda:Portunidae), in Morton Bay, Queensland (Australia). Australia Journal of Marine and Freshwater Research 36, 773-783.

Ihwan, M.Z., Nursilawati, M.K., Ikhwanuddin, M., Azmie, G. \& AbolMunafi, A.B. (2011). Catch fishery information of mud crab, genus Scylla from Kelantan mangrove forest of Peninsular Malaysia. In 8th Annual Seminar on Marine Science and Aquaculture. Universiti Malaysia Sabah, Kota Kinabalu, Sabah. Abstract.

Ikhwanuddin, M., Azmie, G., Juariah, H.M., Zakaria, M.Z. \& Ambak, M.A. (2011). Biological information and population features of mud crab, genus Scylla from mangrove areas of Sarawak, Malaysia. Fisheries Research 108, 299-306.

Ikhwanuddin, M., Bachok, Z., Hilmi, M.G., Azmie, G. \& Zakaria, M.Z. (2010). Species diversity, carapace width-body weight relationship, size distribution, and sex ratio of mud crab, genus Scylla from Setiu wetlands of Terengganu coastal waters, Malaysia. Journal of Sustainability and Management 5, 97-109.

Ikhwanuddin, M., Fazhan, M.M.H., Ho, K.W., Wong, L. \& Abol Munafi, A.B. (2014). First record of mud crab, Scylla serrata (Forskål, 1775) from Malaysia coastal waters: A comparative diagnosis. In International Conference on Marine Science and Aquaculture. Universiti Malaysia Sabah, Kota Kinabalu, Sabah. Abstract.

Jirapunpipat, K. (2008). Population structure at size of maturity of the orange mud crab Scylla olivacea in Klong Ngao Mangrove Swamp, Ranong Province, Thailand. Kasetsart Journal (Natural Sciences) 42, 31-40.

Keenan, C.P., Davie, P.J.F. \& Mann, D.L. (1998). A revision of the genus Scylla de Haan, 1833 (Crustacea: Decapoda: Brachyura: Portunidae). Raffles Bulletin Zoology 46, 217-245.

Keenan, C.P. (1999). Aquaculture of mud crab, genus Scylla past, present and future. In ACAIR International Scientific Forum Mud Crab Aquaculture And Biology. (C.P. Keenan and A. Blackshaw eds.) pp 9-13. Darwin, Australia.

Sara, L. (2010). Study on the size structure and population parameters of mud crab Scylla serrata in Lawele bay, southeast Sulawesi, Indonesia. Journal of Coastal Development 13, 133- 147.

Le Vay, L., Ut, V.N. \& Jones, D.A. (2001). Seasonal abundance and recruitment in an estuarine population of mud crabs, Scylla paramamosain, in the Mekong Delta, Vietnam. Hydrobiologia 449, 231239.

Le Vay, L. (2001). Ecology and management of mud crab Scylla spp. Asian Fisheries Science 14, 101-111.
Lebata, J.H.L., Le Vay, L., Primavera, J.H., Walton, M.E.M. \& Bĩnas, J.B. (2007). Population and fisheries of Scylla spp. in the mangroves of Naisud and Bugtong Bato, Ibajay, Aklan, Philippines. Bulletin of Marine Science 80, 891-904.

Nirmala, V.H., Gangan, S.S., Yadav, B.M., Durgale, P. \& Shinde, K.M. (2012). Traditional knowledge on mud crab: Ethnoecology of Scylla serrata in Ratnagiri Coast, Maharasta. Indian Journal of Traditional Knowledge 11, 317-322.

Noor Amalia, S.K. (2016). Annual reproductive cycle of mud crab genus Scylla in Marudu Bay, Sabah. Master Thesis, Universiti Malaysia Sabah.

Nurul Ain, M.S. (2016). Species composition, distribution and genetic diversity of mud crabs genus Scylla in selected mangrove areas of Sabah. Master Thesis, Universiti Malaysia Sabah.

Pillans, S., Pillans, R.D., Johnstone, R.W., Kraft, P.G., Haywood, M.D.E. \& Possingham, H.P. (2005). Effects of marine reserve protection on the mud crab Scylla serrata in a sex-biased fishery in subtropical Australia. Marine Ecology Progress Series 295, 201-213.

Ransangan, J., \& Tan, K. S. (2018). Occurrence and distribution of marsh clam, Polymesoda spp.in Marudu Bay, Sabah, Malaysia. Open Journal of Marine Science 8, 314-322.

Shelley, C. and Lovatelli, A. (2011). Mud Crab Aquaculture: A Practical Manual. Food and Agriculture Organization of the United Nation, Fisheries and Aquaculture Technical Paper No. 567, Rome, Italy. pp 78

Stamatopoulos, C. (2002). Sample-based fishery surveys: a technical handbook. Food and Agriculture Organization of the United Nation, Fisheries Technical Paper 425, Rome, Italy. pp 132.

Tongdee, N. (2001). Size distributions, sex ratio and size at maturity of mud crab (Scylla spp.) in Ranong province Thailand. Asian Fisheries Science $113-120$

Walton, M.E.M., Le Vay, L., Lebata, J.H., Binas, J. \& Primavera, J.H. (2006). Seasonal abundance, distribution and recruitment of mud crabs (Scylla spp.) in replanted mangroves. Estuarine, Coastal and Shelf Science 66, 493- 500 .

Ward, T.M., Schmarr, D.W. \& McGarvey, R. (2007). Northern Territory mud crab fishery: 2007 stock assessment. Report to Northern Territory Department of Primary Industries and Mines. South Australian Research and Development Institute, Research Report Series No. 244. 